http://dx.doi.org/10.18778/1508-1117.25.06

Marcin Wójcik

\title{
UWARUNKOWANIA TWORZENIA „SIECI NAJCIEKAWSZYCH WSI" WYNIKI OCENY EKSPERCKIEJ 50 POLSKICH MIEJSCOWOŚCI
}

Zarys treści Celem opracowania jest interpretacja wyników oceny eksperckiej 50 polskich wsi, które charakteryzują się dużymi walorami kulturowymi. Ocena grupy miejscowości wiejskich miała na celu określenie możliwości utworzenia „Sieci Najciekawszych Wsi”. W artykule przedstawiono podstawy metodyczne oceny oraz zróżnicowanie grupy wsi w zakresie wybranych cech. Celem tworzącej się „Sieci Najciekawszych Wsi" jest budowa markowego produktu turystycznego na obszarach wiejskich. Tworzenie „Sieci Najciekawszych Wsi” jest procesem długofalowym, któremu towarzyszy wiele celów w różnych aspektach funkcjonowania wiejskich miejscowości. Operatorem powstającego produktu markowego jest Polska Sieć Odnowy i Rozwoju Wsi (PSORW) - stowarzyszenie ok. 50 podmiotów, głównie samorządów gminnych. Rozkład przestrzenny wybranych do projektu 50 wsi pokazał, że największe zasoby materialnego dziedzictwa kulturowego charakteryzują się regiony, w których przeważała bardziej trwała zabudowa mieszkaniowa i gospodarcza (cegła, kamień, szachulec) przed II wojną światową tj. w obszarach przyłączonych do Polski w 1945 roku (zachodniopomorskie, lubuskie, dolnośląskie, opolskie, warmińsko-mazurskie). Stan zachowania oryginalnych układów przestrzennych oraz fizjonomicznych zależał w dużej mierze od intensywności powojennych przekształceń osadnictwa wiejskiego pod wpływem industrializacji i urbanizacji. Stosunkowo dużo interesujących pod tym względem wsi znajduje się w rolniczych obszarach województwa podlaskiego, lubelskiego, małopolskiego, podkarpackiego. Wśród najlepiej ocenionych aspektów znalazły się: przyroda i krajobraz wewnątrz miejscowości, wyróżniki wsi, wjazdowe ciągi komunikacyjne, obiekty zabytkowe, przyroda i krajobraz w otoczeniu, układ ruralistyczny. Najsłabiej podczas oceny wypadły następujące aspekty: charakter i stan ogrodzeń, stan techniczny zabudowy, usługi, produkty, pamiątki, system opisu trasy, miejsca dla turystów, system informacji wizualnej.

Słowa kluczowe Wieś, dziedzictwo kulturowe, metody badań osadnictwa. 


\section{Wprowadzenie}

Współcześnie powstaje wiele prac naukowych na temat przemian polskiej wsi, co niewątpliwie związane jest z ożywieniem sytuacji społeczno-gospodarczej wielu obszarów wiejskich po wejściu Polski w struktury Unii Europejskiej. Uruchomienie programów rozwoju wsi z powodzeniem aktywizuje procesy modernizacji rolnictwa, przemysłu rolno-spożywczego, wzmacnia przedsiębiorczość oraz różne działania lokalnych społeczności. Zauważa się w tym zakresie dość duże nierówności rozwojowe zarówno regionalne, jak i lokalne (por. np. Rudnicki 2010; Biczkowski 2013). Należy pamiętać, że środki europejskie są jednym z wielu czynników, które wpływają na procesy rozwoju lokalnego, a jednym z kluczowych uwarunkowań modernizacji jest kapitał społeczny, czyli zdolność społeczności terytorialnych do samoorganizacji i wspólnego działania. Zasoby tego kapitału wpływają na przekształcenia struktur społeczno-ekonomicznych, w tym również organizację systemów osadniczych (Wójcik 2012).

Jednym z problemów przekształceń obszarów wiejskich są przemiany krajobrazu kulturowego, zwłaszcza w zakresie jego spójności funkcjonalno-użytkowej oraz estetyczno-fizjonomicznej. Trudności we właściwym kształtowaniu krajobrazów wiejskich warunkowane są wieloma czynnikami, z których jednym z najbardziej istotnych jest mentalność mieszkańców wsi odziedziczona po poprzednim systemie społeczno-gospodarczym i jego ideologii rozwoju (socjalistyczna modernizacja). „Wiejskość” przez wiele dziesięcioleci była czymś wstydliwym, wystawionym na krytykę ówczesnych ideologów modernizacji społecznej opartej na prymacie przemysłu ciężkiego, kolektywizacji oraz urbanizacji (por. np. Bukraba-Rylska 1992; Wójcik 2012; Niedźwiedzka-Filipiak, Wilczyński 2015). Regionalny charakter wiejskiej przestrzeni w rozmaity sposób bezrefleksyjnie niszczono, co przejawiało się nie tylko w próbie dokonania rozkładu więzi społecznych i osłabieniu tożsamości kulturowej, ale również w promowaniu wzorca zagospodarowania przestrzennego polegającego na odejściu od regionalizmu architektonicznego na rzecz siermiężnych projektów realizowanych wszędzie niezależnie od charakteru środowiska przyrodniczego i kulturowego. Przekształcenia architektoniczno-fizjonomiczne wsi, degradacja wielu cennych obiektów dziedzictwa kultury szlacheckiej i chłopskiej oraz mniejszości narodowościowych i religijnych doprowadziły do ogromnych spustoszeń w walorach krajobrazowych. Zniknęło w dużej mierze to, co można nazwać kompleksowym charakterem dziedzictwa kulturowego wsi, tzn. integralnym współwystępowaniem w miejscach (wsiach, zespołach wsi, regionach kulturowych) różnego typu cennych obiektów, tj. sakralnych, rezydencjalnych, mieszkaniowych, gospodarczych, 
infrastrukturalnych wraz z całą społeczną treścią tworzoną przez instytucje „długiego trwania" i świadomych tych wartości kulturowych ludzi (Wójcik 2012) ${ }^{1}$.

Odnowa wsi jest we współczesnych warunkach, zwłaszcza w kontekście określonych projektów realizowanych ze środków UE, pojęciem bardzo szerokim, obejmującym rewitalizację obiektów różnego typu, poprawę estetyki i zagospodarowania przestrzeni publicznej, inwestycje w infrastrukturę, wzmacnianie kapitału społecznego oraz tożsamości miejsc, tj. kulinaria, działalność kulturalna, oświatowa itp. (por. Kłodziński i in. 2007; Wójcik 2010; Wilczyński 2012a; Idziak, Wilczyński 2013). Jednym z najsłabszych punktów obiektywnej i realistycznej oceny walorów kulturowych wsi jest brak kompleksowej wiedzy na temat ich zakresu, zarówno ilościowego i jakościowego. Wiedza ta jest fragmentaryczna zarówno w sensie terytorialnym, jak i instytucjonalnym. W wymiarze terytorialnym lepiej zinwentaryzowane są utrwalone pod względem intensywności ruchu turystycznego (przewodniki, mapy, źródła internetowe, fora dyskusyjne itp.) oraz koncentracji walorów o znacznej wartości historycznej (regiony turystyczne i „silne” regiony kulturowe różnych typów - historyczne, etnograficzne). W wymiarze instytucjonalnym fragmentaryzm polega głównie na niespójności wiedzy będącej w posiadaniu instytucji odpowiedzialnych za przechowywanie takich danych (np. konserwatorzy zabytków, instytucje samorządów terytorialnych, jednostki naukowo-badawcze), zwłaszcza w zakresie ich przestrzennej lokalizacji i wynikających z tego różnych powiązań bliskiego zasięgu (przestrzenne, funkcjonalne, społeczne).

Próby inwentaryzacji i oceny wielkości zachowanego dziedzictwa kulturowego w obszarach wiejskich, zwłaszcza peryferyjnych, wymaga wiedzy pochodzącej z wielu źródeł, tym bardziej, że informacje ujęte w ewidencjach są w wielu przypadkach zdezaktualizowane, głównie na skutek współczesnych procesów niszczenia obiektów o dużych wartościach historyczno-kulturowych, zwłaszcza będących w rękach prywatnych (szczególnie zabytkowa zabudowa zagrodowa). Szansą na odwrócenie niekorzystnych trendów w tym zakresie są działania, które przyjmują charakter zinstytucjonalizowany, tzn. poza miejscowym wymiarem aktywności liderów zainteresowanych twórczym rozwojem dziedzictwa kulturowego, przyjmują charakter sieci - grupy powiązanej celem nadrzędnym o wspólnych podstawach organizacyjnych, zasadach funkcjonowania i planach rozwoju $\mathrm{z}$ centralnymi organami tworzenia regulacji w tym zakresie.

${ }^{1}$ Por. również pracę I. Niedźwiedzkiej-Filipiak (2009) nt. wyróżników krajobrazu kulturowego wsi. 


\section{Cel i metodyka badań}

Celem opracowania jest interpretacja wyników oceny eksperckiej 50 polskich wsi, które charakteryzują się dużą koncentracją walorów kulturowych - materialnych, instytucjonalnych i duchowych. Ocena grupy miejscowości wiejskich miała na celu określenie możliwości utworzenia "Sieci Najciekawszych Wsi” (SNW). W artykule przedstawiono zakres (podstawy merytoryczne) oceny, zróżnicowanie grupy wsi w zakresie wybranych cech oraz podstawowe problemy ochrony i kształtowania cennych układów ruralistycznych ${ }^{2}$.

Celem tworzącej się „Sieci Najciekawszych Wsi” jest budowa markowego produktu turystycznego na obszarach wiejskich. Doświadczenia opolskiego programu odnowy wsi realizowanego od ponad 15 lat były podstawą do opracowania koncepcji merytorycznej oraz podstaw organizacyjnych ogólnopolskiej sieci wsi, których walory mogą zainteresować turystów z Polski, a także z zagranicy (por. Idziak, Wilczyński 2013)33. Oryginalny pomysł sieci interesujących wsi powstał we Francji i znalazł wielu naśladowców, głównie w krajach Unii Europejskiej, a także w Kanadzie i Japonii (por. Wilczyński 2012b). Podstawowym celem rozwojowym jest w każdym przypadku przeciwdziałanie niekorzystnym procesom demograficznym i ekonomicznym takim, jak np. depopulacja, spadek aktywności ekonomicznej, spadek wartości nieruchomości, utrata walorów kulturowych itd. Specyfiką polskiego projektu jest przesunięcie akcentu z określenia „najpiękniejsze” na „najciekawsze”, co związane jest z jednej strony

${ }^{2}$ Projekt „Tworzenie Sieci Najciekawszych Wsi” powstał na zlecenie Fundacji Programów Pomocy dla Rolnictwa (FAPA) podległej Ministerstwu Rolnictwa i Rozwoju Wsi w okresie 16.01.-31.05.2015 r. Inicjatorem i głównym ekspertem projektu „Tworzenie Sieci Najciekawszych Wsi” jest Ryszard Wilczyński (b. Wojewoda Opolski, obecnie poseł na Sejm RP). Kierownictwo merytoryczne projektu i organizacja badań - dr hab. Marcin Wójcik, prof. UŁ. Interdyscyplinarny zespół badawczy w składzie: dr hab. inż. Sylwia Staszewska, prof. UAM (UAM, Poznań), mgr inż. Piotr Staszewski (praktyk, konserwator zabytków, Poznań), dr Konrad Czapiewski i dr Edyta Regulska (PAN, Warszawa), dr Paulina Tobiasz-Lis, dr Karolina Dmochowska-Dudek, dr Tomasz Napierała, dr Pamela Jeziorska-Biel, dr Małgorzata Marks-Krzyszkowska, dr Marcin Feltynowski (UŁ, Łódź), dr Magdalena Dej, mgr Łukasz Sykała (IRM, Kraków), dr Krzysztof Janc, dr inż. Paulina Dudzik-Deko (UWr, Wrocław). Operatorem tworzącej się Sieci Najciekawszych Wsi jest Polska Sieć Odnowy i Rozwoju Wsi (PSORW) z siedzibą Sekretariatu w Urzędzie Miasta Gogolin (Województwo Opolskie).

${ }^{3}$ Zainteresowanym historią programu odnowy wsi w województwie opolskim można polecić prace autorstwa W. Idziaka i R. Wilczyńskiego (2013) oraz strony internetowe http://www.dziedzictwowsiopolskiej.pl/ i http://www.odnowawsi.eu/, gdzie zamieszczone są liczne materiały prezentujące podstawy merytoryczne i organizacyjne projektów $\mathrm{z}$ ostatnich 15 lat. 
z dość dużą degradacją wartości dziedzictwa materialnego w skali całego kraju, a także podkreśleniem roli różnych procesów społeczno-ekonomicznych, które prowadzą współcześnie do wzrostu znaczenia wsi i ich ponadlokalnego oddziaływania. Stworzenie takiej sieci to szansa kultywowania wiejskości i zachowanie wiejskiego dziedzictwa kulturowego, a także uzyskanie przez wieś możliwości rozwoju oraz poprawy jakości życia mieszkańców (Niedźwiedzka-Filipiak, Wilczyński 2015).

Tworzenie „Sieci Najciekawszych Wsi” jest procesem długofalowym, rozciągniętym w czasie, któremu towarzyszy wiele celów w różnych aspektach funkcjonowania wiejskich miejscowości. Operatorem powstającego produktu markowego jest Polska Sieć Odnowy i Rozwoju Wsi (PSORW) - stowarzyszenie ok. 50 podmiotów, głównie samorząáw gminnych, którego celem jest wymiana doświadczeń, wiedzy o dobrych praktykach w zakresie wzrostu społeczno-gospodarczego obszarów wiejskich ${ }^{4}$. Działalność tego stowarzyszenia była kluczowa dla zinstytucjonalizowania tworzenia „Sieci Najciekawszych Wsi”, a tym samym uruchomienia mechanizmu wyłaniania kandydatów, opracowywania zasad funkcjonowania i rozwoju elitarnej grupy miejscowości wiejskich. Pomysł zrodzony w czasie pierwszych doświadczeń Polski jako członka UE powinien zostać zrealizowany do 2017 roku, kiedy sieć zacznie realnie funkcjonować w oparciu o jednolite zasady planu działań, kreowania wizerunku, marki turystycznej itd.

W 2015 roku działania PSORW ukierunkowane były na wdrażanie projektu Sieci w zakresie oceny walorów kulturowych pierwszych 50 wsi z listy 100 jednostek wyłonionych przez członków stowarzyszenia na bazie informacji własnych, a także przekazanych przez konserwatorów zabytków oraz instytucje samorządowe szczebla regionalnego (rys. 1). Projekt był realizowany ze środków Programu Rozwoju Obszarów Wiejskich (2007-2013) na zlecenie Fundacji Programów Pomocy dla Rolnictwa FAPA podległej Ministerstwu Rolnictwa i Rozwoju Wsi w okresie 01-05.2015 r. Wyboru 50 wsi z listy 100 przedstawionych dokonał kierownik merytoryczny projektu na podstawie wstępnej oceny wszystkich jednostek osadniczych w trzech zakresach, tj. zachowanie historycznego układu przestrzennego i stopień jego przekształcen, aktywność społeczna oraz wpisanie $\mathrm{w}$ walory przyrodnicze $\mathrm{i}$ antropogeniczne regionu. Jedną z zasad było zaproszenie do projektu wsi z każdego województwa Polski (przynajmniej 1 wieś pozyskana do projektu z każdego województwa). Pilotażowy projekt został przeprowadzony wcześniej w województwie opolskim w oparciu o środki Krajowej Sieci Obszarów Wiejskich (KSOW).

\footnotetext{
${ }^{4}$ Więcej informacji na stronie http://www.psorw.odnowawsi.pl/.
} 


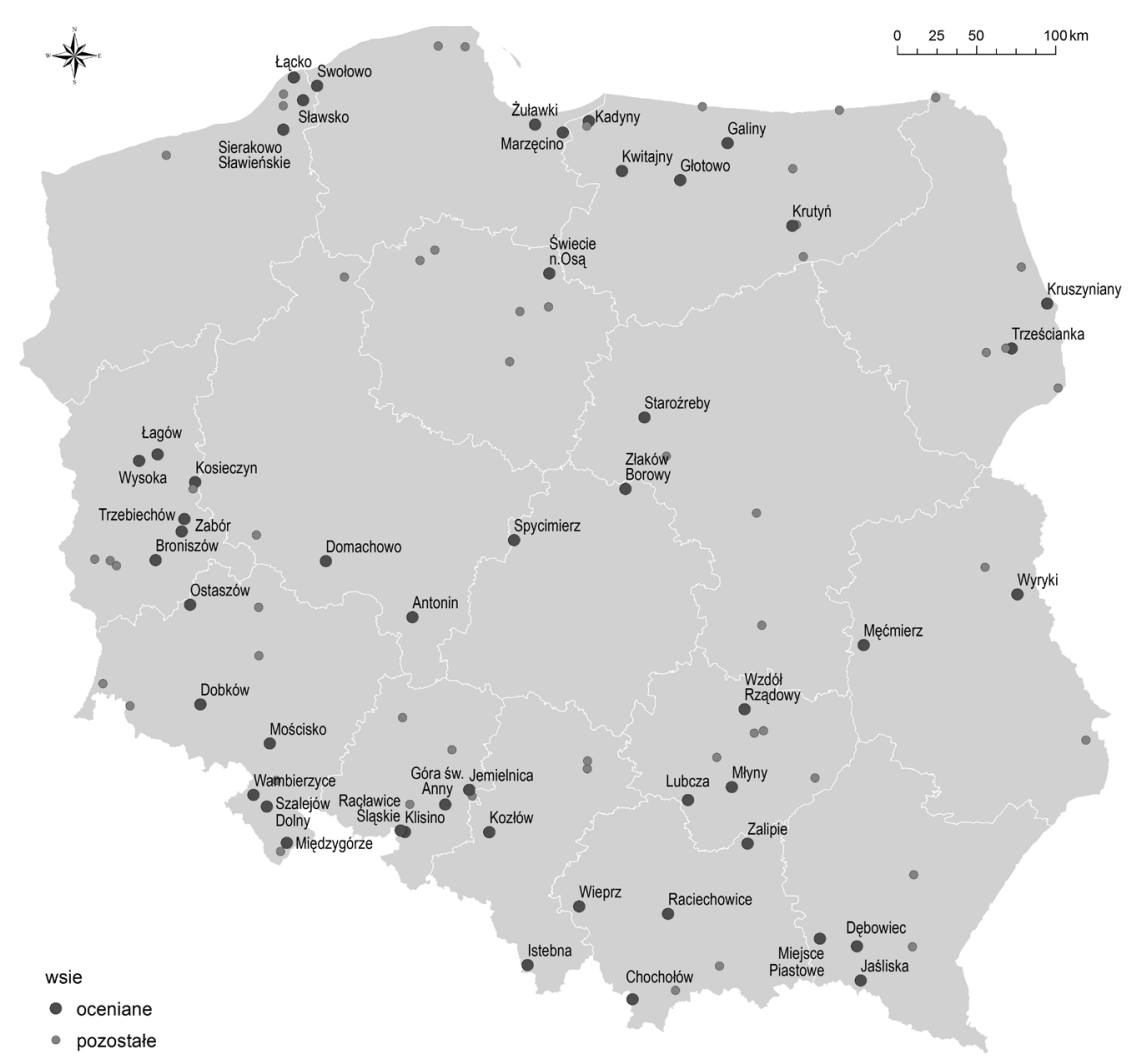

Rys. 1. Rozmieszczenie wsi zgłoszonych (100) i ocenionych (50) w okresie styczeń-maj 2015 Źródło: opracowanie własne

Rozmieszczenie wsi z listy otrzymanej od FAPA jest przede wszystkim funkcją stanu zachowania dziedzictwa kulturowego, zwłaszcza materialnego, polskiej wsi. Rozkład przestrzenny wybranych do projektu 50 wsi w dużym stopniu nawiązał do rozmieszczenia wszystkich miejscowości znajdujących się na liście. Wpływ na liczbę miejscowości miało również zaangażowanie w projekt regionalnych instytucji samorządowych oraz ochrony dziedzictwa kulturowego. Duże zainteresowanie projektem miało miejsce w regionie lubuskim, opolskim, dolnośląskim, warmińsko-mazurskim.

Rozmieszczenie wsi na terenie Polski pokazuje, że największymi zasobami materialnego dziedzictwa kulturowego charakteryzują się regiony, w których przeważała bardziej trwała zabudowa mieszkaniowa i gospodarcza (cegła, kamień, szachulec) przed II wojną światową - tj. w obszarach przyłączonych do Polski w 1945 roku (zachodniopomorskie, lubuskie, dolnośląskie, opolskie, warmińsko- 
-mazurskie). Stan zachowania oryginalnych układów przestrzennych oraz fizjonomicznych zależał w dużej mierze od intensywności powojennych przekształceń osadnictwa wiejskiego pod wpływem industrializacji i urbanizacji. Stosunkowo dużo interesujących pod tym względem wsi znajduje się w rolniczych obszarach województwa podlaskiego, lubelskiego, małopolskiego, podkarpackiego. Nieodwracalne zniszczenia dokonały się natomiast $\mathrm{w}$ regionach centralnych, tj. łódzkie, mazowieckie, świętokrzyskie, kujawsko-pomorskie, gdzie drewniana zabudowa została zastąpiona przez murowaną, a proces ten charakteryzował się brakiem namysłu nad wartością historyczną ruralistycznych układów. W konsekwencji w Polsce środkowej materialne dziedzictwo kulturowe wsi można obejrzeć prawie wyłącznie w skansenach.

Ocena wielkości potencjału wsi opiera się na wielokryterialnej metodzie pracy terenowej oraz kameralnej, której podstawą jest arkuszu ewaluacyjny, czyli Karta Oceny Miejscowości (KOM). Jej kształt jest efektem wieloletnich prób opracowania narzędzia, dzięki któremu zasoby kulturowe wsi można ocenić w wielu obszarach i aspektach (por. Niedźwiedzka-Filipiak, Wilczyński 2015). Podstawą konstrukcji karty jest nadanie określonych wag punktowych obszarom, podobszarom merytorycznym i ich elementom składowym, a następnie rozdzielenie punktów pomiędzy aspekty oraz ostatecznie nadanie im określonego waloru punktowego podczas oceny eksperckiej (por. Niedźwiedzka-Filipiak, Wilczyński 2015, s. 98-100).

Idea identyfikacji zasobów kulturowych ciekawych wsi odnosi się do podziału wsi na dwa typy, tj. wsi dziedzictwa kulturowego o relatywnie wysokich walorach historycznych, zwłaszcza architektoniczno-fizjonomicznych oraz wsi przeżyć i emocji, które mogą być atrakcyjne ze względu na specyfikę i ofertę pobytu. $\mathrm{W}$ koncepcji tej istotną sprawą jest związek pomiędzy tworzeniem markowego produktu a realizacją paradygmatu rewitalizacji, w tym wewnętrznego rozwoju wsi (por. Niedźwiedzka-Filipiak, Wilczyński 2015).

Ocena miejscowości oparta jest na kryteriach, które obejmują trzy główne „obszary walorów miejscowości”, tj. zasoby, specyfikę i klimat (por. Niedźwiedzka-Filipiak, Wilczyński 2015 oraz tab. 1). Ich łączne rozpatrywanie decyduje o całościowej ocenie jakości miejsca i oferty, a to z kolei przekłada się na satysfakcję odbiorcy, któremu w trakcie pobytu towarzyszą stany emocjonalne. W koncepcji tworzenia sieci zakłada się, że walory poznawcze są powodem pobytu. Pobyt musi być jednak określony w ścisły sposób, tj. zwerbalizowany w postaci „opowieści” odnoszącej się do konkretnego obszaru, tj. „obszaru udostępnionego” oraz trasy, podczas której poznajemy jej kolejne części, tj. trasy udostępniającej walory wsi (por. Niedźwiedzka-Filipiak, Wilczyński 2015, s. 12). Narracja miejsca ma charakter zrutynizowany do konkretnej drogi oraz czasu, który jest potrzebny na poznanie oraz wywołanie skutków w postaci przeżyć i emocji. 


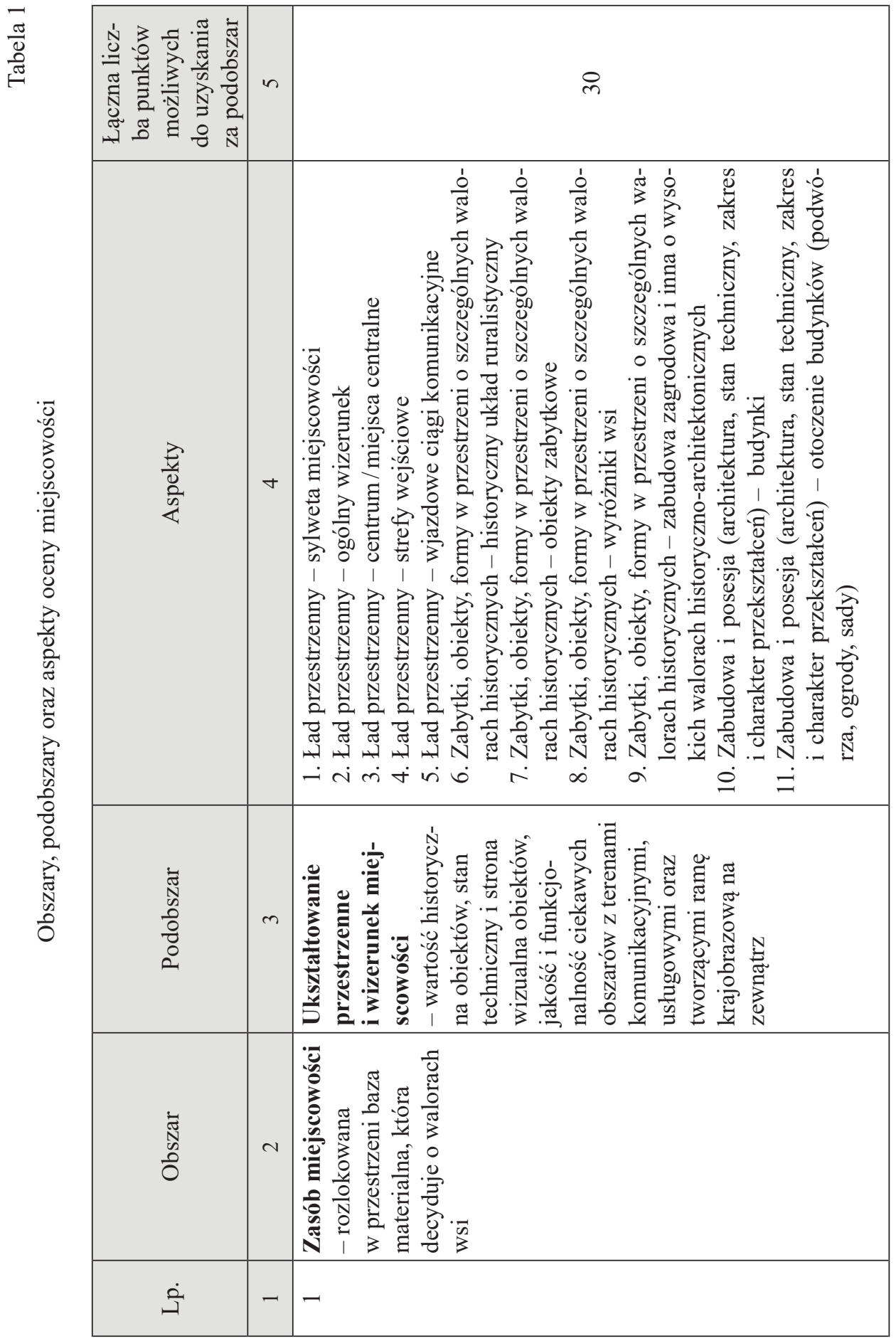




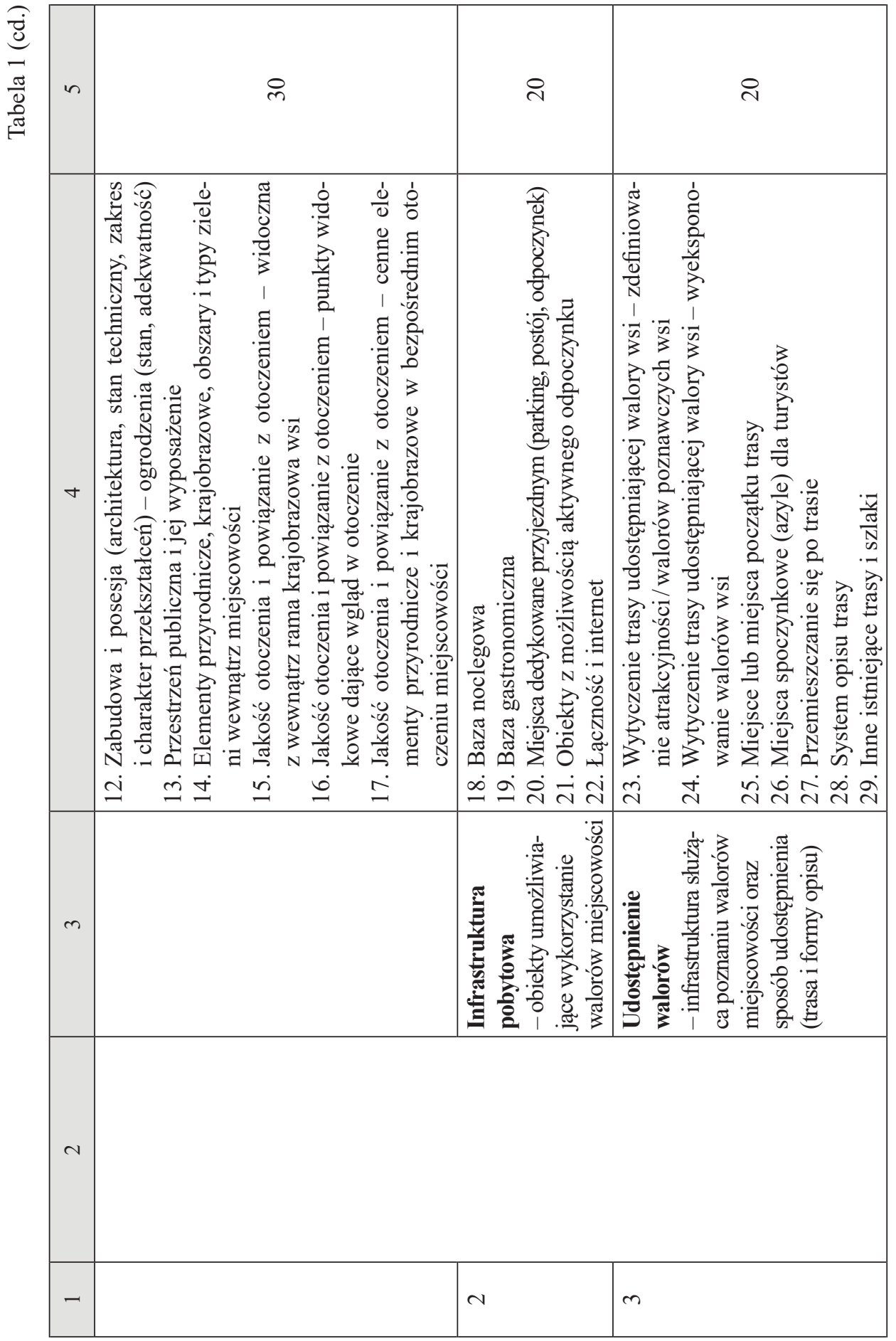


गुं
$\frac{\pi}{0}$
$\frac{\pi}{\pi}$

\begin{tabular}{|c|c|c|c|}
\hline in & $\underline{n}$ & $n$ & 8 \\
\hline$\nabla$ & 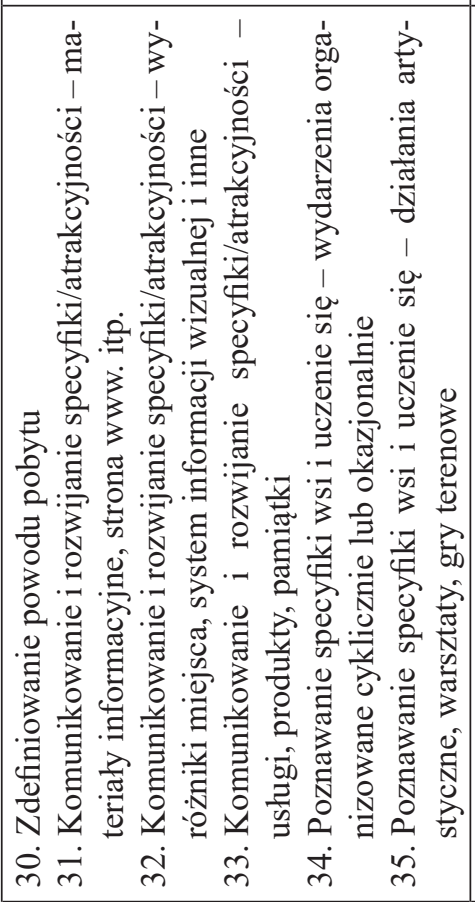 & 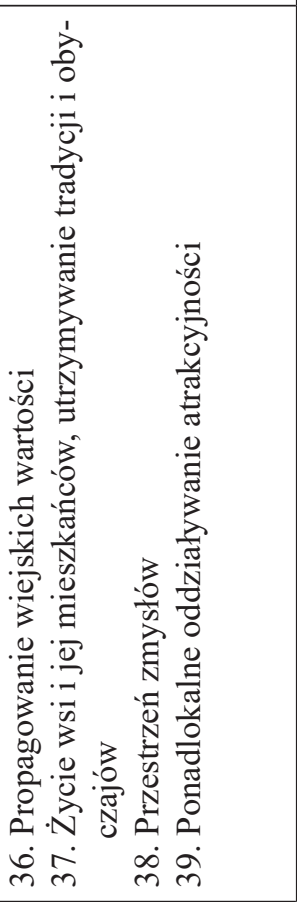 & 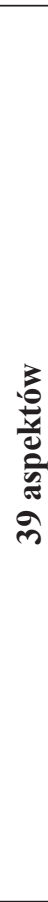 \\
\hline$m$ & \multirow{2}{*}{ 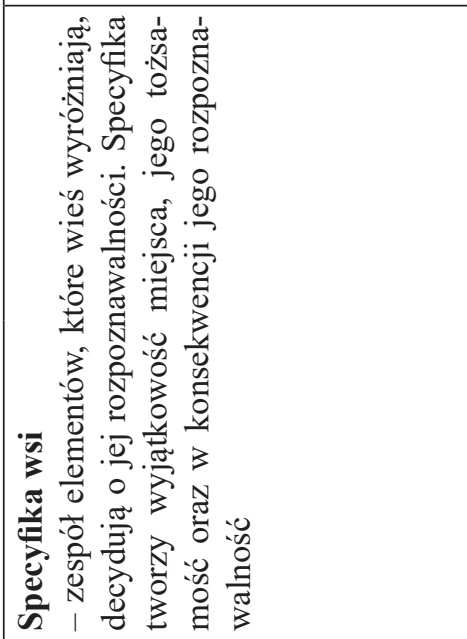 } & \multirow{2}{*}{ 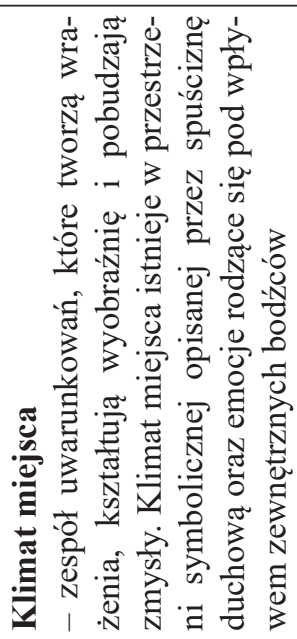 } & 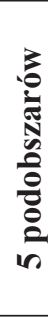 \\
\hline$N$ & & & 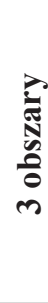 \\
\hline- & I & in & 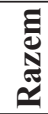 \\
\hline
\end{tabular}




\section{Wyniki badań}

Warunkiem pozytywnej oceny, a tym samym stwierdzenia wystarczających uwarunkowań do uczestnictwa wsi w sieci (SNW) było uzyskanie co najmniej 35 punktów na 100 możliwych do zdobycia oraz brak cech ocenionych na poziomie dyskwalifikującym. Ocenę pozytywną przeszło 46 wsi z 50 zaproszonych do projektu. Wśród czterech ocenionych negatywnie znalazły się: Klisino (opolskie, 30 pkt.), Wzdół Rządowy (świętokrzyskie, 27,5 pkt.), Złaków Borowy (łódzkie, 26 pkt.) i Lubcza (świętokrzyskie, 20 pkt.).

Należy podkreślić, że wyniki oceny były bardzo zróżnicowane. Różnica pomiędzy najlepiej ocenioną wsią, tj. Istebną (śląskie, 79 pkt.) a najsłabszym wynikiem Lubczy wyniosła aż 59 pkt. Średni wynik całej badanej pięćdziesiątki to 51,7 pkt., a odchylenie standardowe $-14,3$ pkt. (por. rys. 2). Podział badanej populacji wg wartości średniej, średniej + odchylenie standardowe oraz średniej odchylenie standardowe, czyli na cztery grupy, bardzo dobrze wpisał się w założenia projektu. Wartość graniczna pomiędzy dwoma najlepszymi grupami (średnia + odchylenie standardowe), tj. 66 pkt. odpowiada zakładanemu na wstępie projektu poziomowi, powyżej którego wsie mogą otrzymać certyfikację, czyli stać się już w najbliższym czasie członkami sieci.

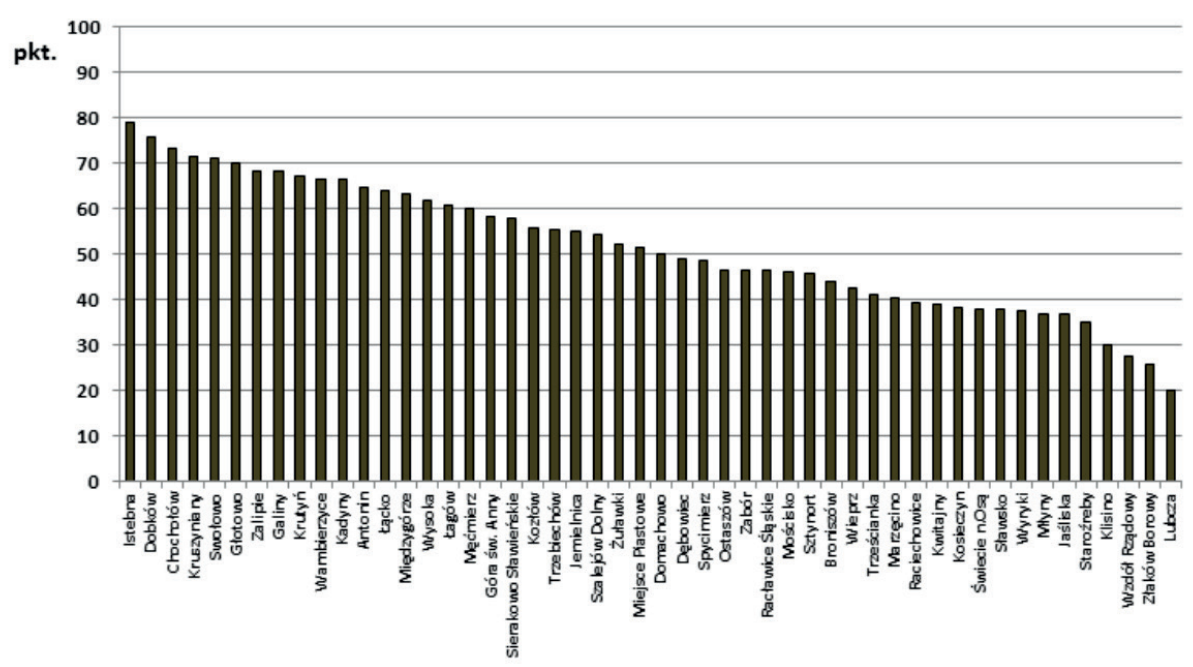

Rys. 2. Ogólny wynik oceny eksperckiej 50 wsi wybranych do badań Źródło: opracowanie własne

Wartość graniczna pomiędzy dwoma słabiej ocenionymi grupami wsi (średnia - odchylenie standardowe), tj. 37,4 pkt. pokrywa się niemal z ustalonym poziomem, poniżej którego miejscowość otrzymywała ocenę negatywną (35 pkt.). 
Stosunkowo równomierny rozkład punktowy oceny eksperckiej 50 wsi dał podstawę do rozbudowy klasyfikacji na pięć grup, gdzie rozpiętość trzech środowych grup wyniosła 10 pkt. (rys. 3, tab. 2). W ten sposób podzielono populację na grupę wsi o bardzo dużym (65 pkt. i więcej) i dużym potencjale do uczestnictwa w sieci (55-64,99 pkt.), potencjale przeciętnym (45-54,99 pkt) oraz potencjale małym $(35-44,99)$ oraz bardzo małym (poniżej 35 pkt.).

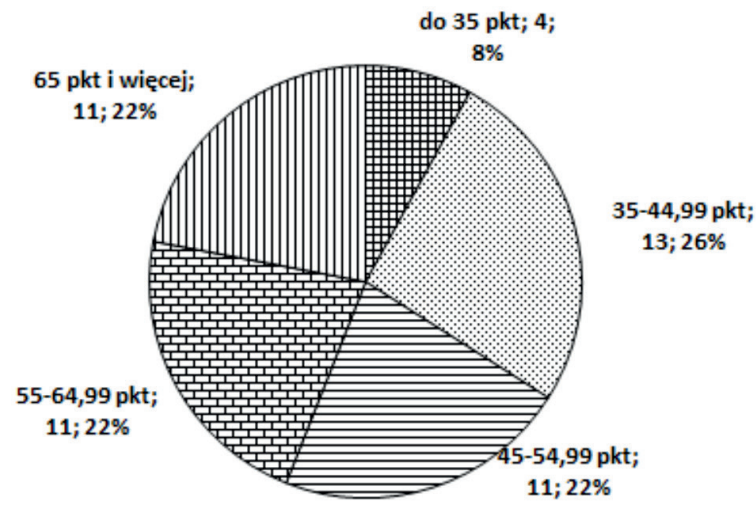

Rys. 3. Liczebność wsi w wyznaczonych grupach oceny

Źródło: opracowanie własne

Tabela 2

Wsie biorące udział w projekcie wg grup oceny

\begin{tabular}{|l|c|l|}
\hline \multicolumn{1}{|c|}{ Grupa } & Liczba wsi & \multicolumn{1}{|c|}{ Wsie } \\
\hline Do 35 pkt. & 4 & Klisino, Wzdół Rządowy, Złaków Borowy, Lubcza \\
\hline 35-44,99 pkt. & 13 & $\begin{array}{l}\text { Broniszów, Wieprz, Trześcianka, Marzęcino, Ra- } \\
\text { ciechowice, Kwitajny, Kosieczyn, Świecie n. Osą, } \\
\text { Sławsko, Wyryki, Młyny, Jaśliska, Staroźreby }\end{array}$ \\
\hline $45-54,99$ pkt. & 11 & $\begin{array}{l}\text { Szalejów Dolny, Żuławki, Miejsce Piastowe, Do- } \\
\text { machowo, Dębowiec, Spycimierz, Ostaszów, Zabór, } \\
\text { Racławice Śląkie, Mościsko, Sztynort }\end{array}$ \\
\hline $55-64,99$ pkt. & 11 & $\begin{array}{l}\text { Antonin, Lącko, Międzygórze, Wysoka, Łagów, } \\
\text { Męćmierz, Góra św. Anny, Sierakowo Sławieńskie, } \\
\text { Kozłów, Trzebiechów, Jemielnica }\end{array}$ \\
\hline 65 pkt. i więcej & 11 & $\begin{array}{l}\text { Istebna, Dobków, Chochołów, Kruszyniany, Swoło- } \\
\text { wo, Głotowo, Zalipie, Galiny, Krutyń, Wambierzy- } \\
\text { ce, Kadyny }\end{array}$ \\
\hline
\end{tabular}

Źródło: opracowanie własne. 
Rozmieszczenie przestrzenne wsi poszczególnych grup pozwala na określenie prawidłowości (rys. 4). Okazuje się bowiem, że istnieje związek pomiędzy położeniem wsi (region) a poziomem oceny. Relatywnie wyższe oceny otrzymały wsie w regionach, które charakteryzują się najlepszym stanem zachowania dziedzictwa kulturowego, czyli w województwie dolnośląskim, lubuskim, opolskim, zachodniopomorskim i warmińsko-mazurskim. Wsie o stwierdzonym bardzo dużym i dużym potencjale do uczestnictwa w „Sieci Najciekawszych Wsi” tworzą zgrupowania przestrzenne - perspektywiczne klastry, co może ułatwić ich dalsze funkcjonowanie na rynku usług turystycznych (wymiana doświadczeń, wspólne problemy, możliwości finansowania rozwoju z tych samych źródeł). W pozostałych regionach wysoko ocenieni kandydaci do sieci są pojedynczymi przypadkami wybijającymi się przede wszystkim wysoką świadomością własnego waloru i stworzoną już własną marką turystyczną, tj. Kruszyniany, Chochołów, Zalipie, Istebna, Męćmierz.

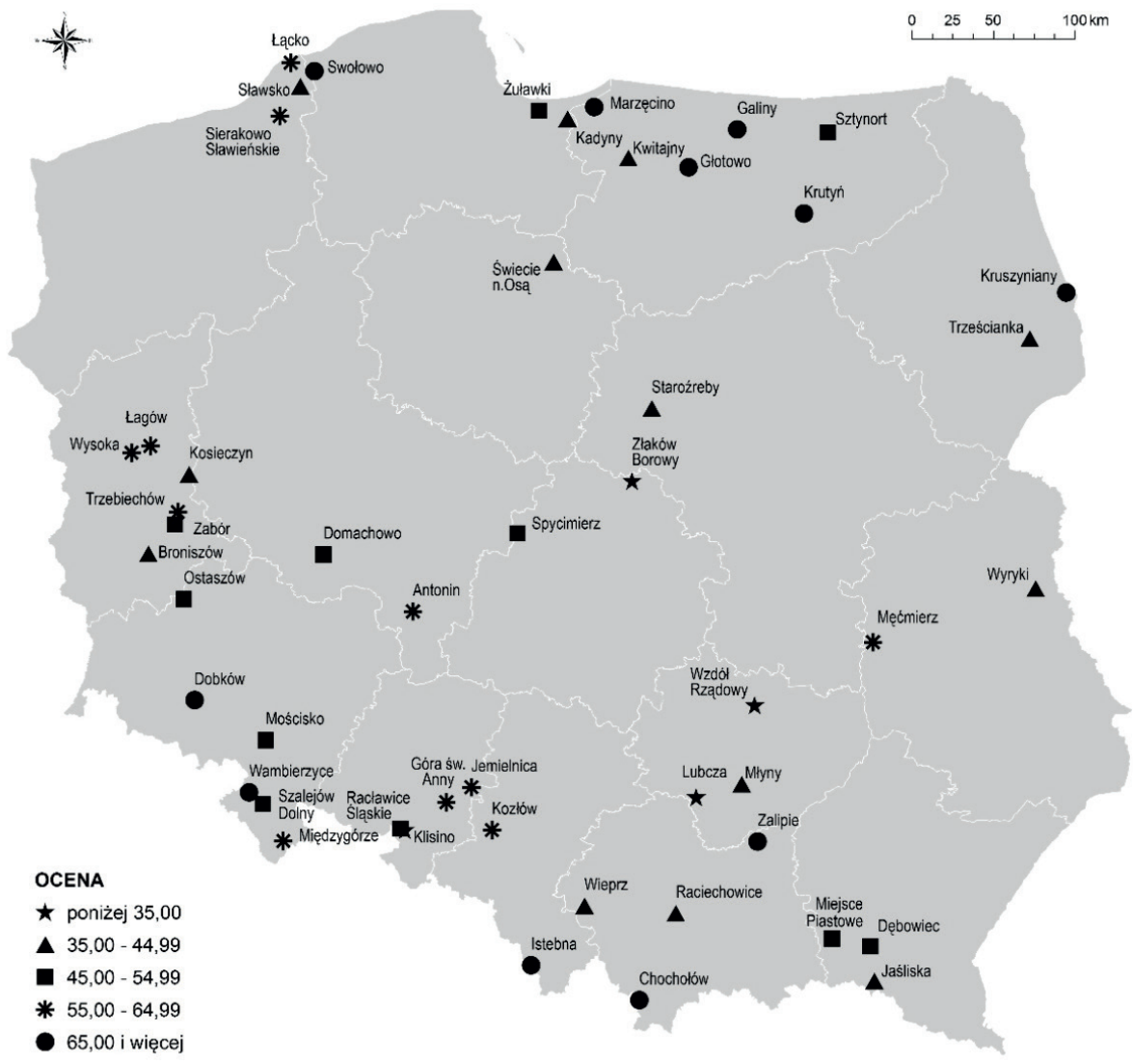

Rys. 4. Ocena punktowa badanych wsi (wg grup) w przestrzeni kraju Źródło: opracowanie własne 
Wśród pięciu wyznaczonych obszarów oceny merytorycznej miejscowości najlepiej zostały ocenione aspekty w zakresie ukształtowania i wizerunku miejscowości (rys. 5). Na kolejnych dobrych miejscach znalazły się sposób, w jaki mieszkańcy proponują udostępnić zasoby wsi oraz specyfika wsi, czyli zespół elementów, które decydują o rozpoznawalności wsi oraz jej obecnej oferty. Najsłabiej ze wszystkich aspektów wypadły te, które związane są z obecnością i funkcjonowaniem infrastruktury pobytowej, czyli wszystkie obiekty i urządzenia mające za zadanie zatrzymanie odwiedzających jak najdłużej na terenie wsi, a tym samym budujące lub wzmacniające podstawy ekonomiczne miejscowości. Można zatem stwierdzić, że istniejące zasoby oraz ich społeczna świadomość w dużej części miejscowości tworzą istotny walor poznawczy. Jednak niedobory wynikające ze słabej promocji tego co wartościowe oraz brak możliwości dłuższego obcowania z lokalnym środowiskiem są na chwilę obecną w większości miejscowości podstawowymi barierami dla wejścia wsi do sieci. Wsie - liderów w wyznaczonych obszarach ocenv przedstawiono w tab. 3 .

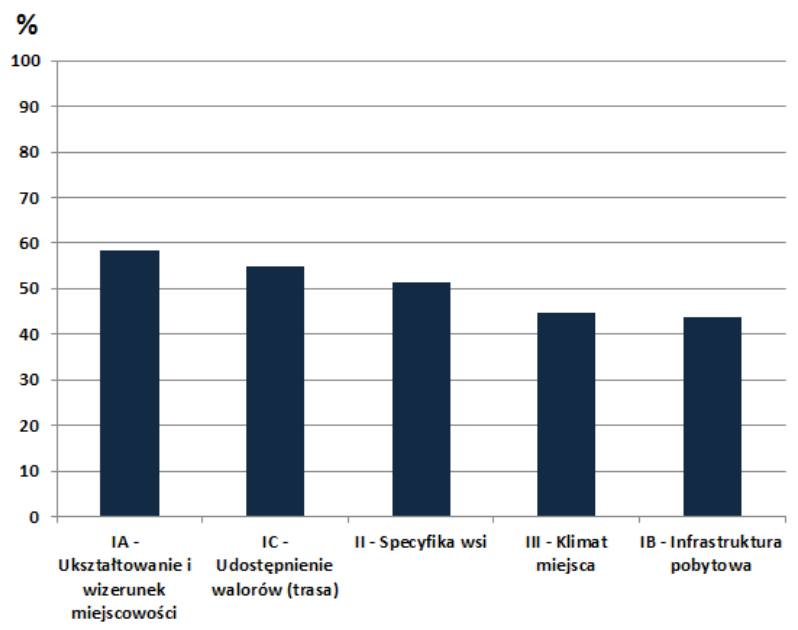

Rys. 5. Średnia wartość w poszczególnych obszarach oceny w stosunku do maksymalnej możliwej do zdobycia liczby punktów (\%)

Źródło: opracowanie własne

Bardziej dokładne określenie cech, które zostały średnio najlepiej i najgorzej ocenione podczas badań pozwala z jednej strony ukazać mocne i słabe strony osadnictwa wiejskiego pod względem uczestnictwa w „Sieci Najciekawszych Wsi”, z drugiej zaś wskazać kluczowe obszary interwencji, która ma służyć podnoszeniu walorów miejscowości. Wśród najlepiej ocenionych aspektów znalazły się:

1. Przyroda i krajobraz wewnątrz miejscowości - zróżnicowanie przyrodnicze i krajobraz wewnątrz miejscowości zostały relatywnie najwyżej ocenione, a składa się na to w dużej mierze stosunkowo dobrze zachowana i pielęgno- 
Wsie - liderzy obszarów oceny merytorycznej

\begin{tabular}{|c|c|c|c|c|}
\hline $\begin{array}{c}\text { Ukształtowanie } \\
\text { i wizerunek } \\
\text { miejscowości }\end{array}$ & $\begin{array}{c}\text { Infrastruktura } \\
\text { pobytowa }\end{array}$ & $\begin{array}{c}\text { Udostępnienie } \\
\text { walorów } \\
\text { (trasa) }\end{array}$ & Specyfika wsi & Klimat miejsca \\
\hline $\begin{array}{l}\text { - Glotowo } \\
\text { (warmińsko- } \\
\text {-mazurskie) } \\
\text { - Galiny } \\
\text { (warmińsko- } \\
\text {-mazurskie) } \\
\text { - Kadyny } \\
\text { (warmińsko- } \\
\text {-mazurskie) } \\
\text { - Chochołów } \\
\text { (małopolskie) } \\
\text { - Męćmierz } \\
\text { (lubelskie) }\end{array}$ & $\begin{array}{l}\text { - Międzygórze } \\
\text { (dolnośląskie) } \\
\text { - Antonin } \\
\text { (wielkopol- } \\
\text { skie) } \\
\text { - Krutyń } \\
\text { (warmińsko- } \\
\text {-mazurskie) } \\
\text { - Istebna } \\
\text { (śląskie) } \\
\text { - Kozłów } \\
\text { (śląskie) } \\
\text { - Kruszyniany } \\
\text { (podlaskie) } \\
\text { - Wambierzyce } \\
\text { (dolnośląskie) }\end{array}$ & \begin{tabular}{|c|}
$-\begin{array}{c}\text { Krutyń } \\
\text { (warmińsko- }\end{array}$ \\
-mazurskie) \\
- Łącko \\
(zachodniopo- \\
morskie) \\
- Głotowo \\
(warmińsko- \\
-mazurskie) \\
- Istebna \\
(śląskie) \\
- Swołowo \\
(pomorskie) \\
- Dobków \\
(dolnośląskie)
\end{tabular} & $\begin{array}{l}\text { - Zalipie } \\
\text { (małopolskie) } \\
\text { - Dobków } \\
\text { (dolnośląskie) } \\
\text { - Kruszyniany } \\
\text { (podlaskie) } \\
\text { - Swołowo } \\
\text { (pomorskie) } \\
\text { - Domachowo } \\
\text { (wielkopol- } \\
\text { skie) }\end{array}$ & $\begin{array}{c}\text { - Dobków } \\
\text { (dolnośląskie) } \\
\text { - Zalipie } \\
\text { (małopolskie) } \\
\text { - Chochołów } \\
\text { (małopolskie) } \\
\text { - Swołowo } \\
\text { (pomorskie) } \\
\text { - Istebna } \\
\text { (śląskie) }\end{array}$ \\
\hline
\end{tabular}

Źródło: opracowanie własne.

wana roślinność w przestrzeniach publicznych oraz jej powiązanie z przyrodą otaczającą wieś. Wiele wsi dzięki położeniu w atrakcyjnych pod względem przyrodniczym regionach Polski (urozmaicenie rzeźby, lesistość) ma zróżnicowaną fizjografię, w tym występują tak ważne dla dobrej percepcji krajobrazu elementy, jak rzeki, jeziora, ostańce, wychodnie skał, stanowiska cennej flory.

2. Wyróżniki wsi - każda wieś ma oryginalny charakter jako efekt złożonych uwarunkowań przyrodniczych i kulturowych (regionalnych i lokalnych). Większość miejscowości ma duże możliwości, aby ze swej specyfiki wyodrębnić i pokreślić te elementy, które jednoznacznie będą się z nią kojarzyły na tle innych uczestników sieci najciekawszych wsi oraz sieci osadnictwa wiejskiego w kraju.

3. Wjazdowe ciągi komunikacyjne - większość miejscowości ma zwarte układy osadnicze i wyraźne odseparowanie od innych wsi, przez co ważnym urozmaiceniem krajobrazu są dobrze ukształtowane ciągi komunikacyjne, które najczęściej charakteryzują się rytmem wywołanym przez starodrzew rosnący wzdłuż drogi, pola oraz rzeźbę terenu.

4. Obiekty zabytkowe - dobór miejscowości do oceny wielkości potencjału zakładał istotną rolę materialnego dziedzictwa kulturowego w kreowaniu marki 
większości wsi. Wsie cechowała różnorodność form architektoniczno-krajobrazowych, tj. sakralnych, rezydencjalnych, zagrodowych, użyteczności publicznej, a także małej architektury (fot. 1).

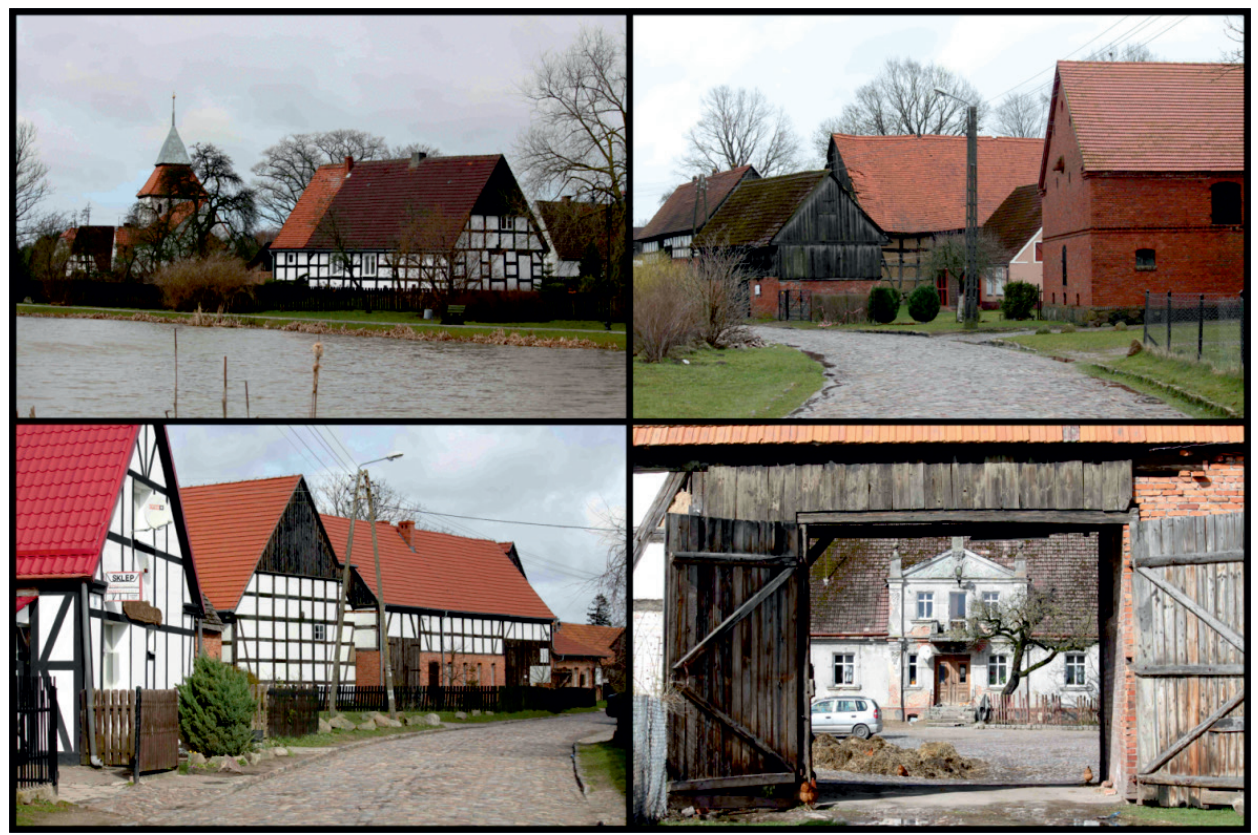

Fot. 1. Swołowo - przykład kandydata do SNW o wysokich walorach opartych na zachowanym materialnym dziedzictwie kulturowym

\section{fot. M. Wójcik}

5. Przyroda i krajobraz w otoczeniu - większość wsi położonych jest w regionalnych peryferiach, przez co stopień przekształcenia krajobrazu jest stosunkowo niewielki (obciążająca krajobraz suburbanizacja, industrializacja, inwestycje komunikacyjne itd.). Również większość wsi leży w atrakcyjnych dla turystyki strefach (pasach) krajobrazowych - nadmorskim, pojeziernym, górskim (fot. 2).

6. Układ ruralistyczny - wsie reprezentują bardzo różne układy morfogenetyczne, najczęściej mają one charakter zwarty, a wiele miejscowości reprezentuje stare formy osadnicze takie, jak wielodrożnice, owalnice, ulicówki, szeregówki, rzędówki. Formy te najczęściej charakteryzują się dobrym lub bardzo dobrym zachowaniem pierwotnego układu siedliska.

7. Rama krajobrazowa (panoramy i osie widokowe) - urozmaicony charakter rzeźby terenu oraz najczęściej niezaburzone nowymi obiektami wnętrze wsi daje możliwość obserwacji otoczenia wsi (z punktów widokowych lub przez „okna” w krajobrazie osadniczym), jak również wzdłuż osi wewnątrz miejscowości. 


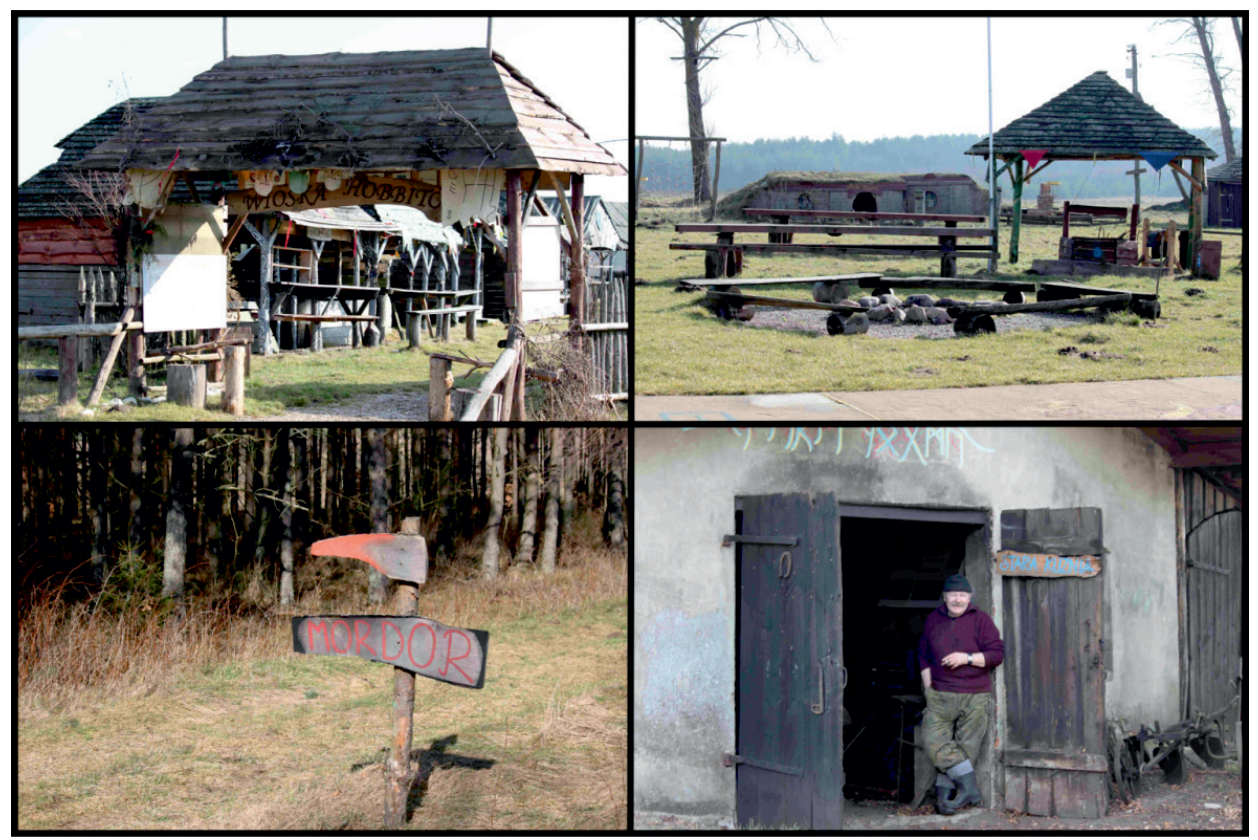

Fot. 2. Sierakowo Sławieńskie - przykład kandydata do SNW o wysokich walorach opartych na walorach niematerialnych (wioska ,przeżyć i emocji”)

fot. M. Wójcik

Najsłabiej podczas oceny wypadły następujące aspekty:

1. Charakter i stan ogrodzeń - jeden z najbardziej dysonujących elementów w krajobrazie wiejskim. Nieadekwatność tego elementu względem obiektów cennych pod względem kulturowym i przyrodniczym, bardzo duże zróżnicowanie materiałowe i estetyczne oraz wewnętrzna niespójność decyduje w największym stopniu o obniżeniu walorów każdej miejscowości.

2. Stan techniczny zabudowy - w większości miejscowości stan techniczny obiektów może przełożyć się w najbliższych latach na utratę kluczowych zasobów kulturowych. Zagrożeniem są również prowizoryczne remonty, niszczenie detali architektonicznych oraz brak społecznego zrozumienia dla wartości obiektów, zwłaszcza gospodarczych.

3. Usługi, produkty, pamiątki - większość wsi nie promuje swojej indywidualności przez sprzedaż choćby drobnych pamiątek, produktów wynikających z podkreślenia specyfiki miejsca.

4. System opisu trasy - wsie bardzo rzadko mają pełny opis informacji o poruszaniu się po obszarze udostępnienia oraz o cennych obiektach lub ważnych wydarzeniach. 
5. Miejsca dla turystów - brak miejsc dedykowanych turystom to jedna z największych przeszkód w zatrzymaniu przyjezdnych na dłużej oraz rozbudzenia w nich pasji poznawczych oraz tworzenia refleksji nad odwiedzanym miejscem.

6. System informacji wizualnej - najczęściej brakuje informacji, która w przestrzeni tworzyłaby narracje miejsca, a także operowałaby swoistą symboliką stworzoną na potrzeby opisu oryginalnych miejsc i tras przejścia.

7. Otoczenie budynków - otoczenie budynków jest najczęściej niespójne z ich charakterem, czego najbardziej negatywnymi przejawami są prowizoryczne przybudówki, nieporządek na posesjach oraz zastępowanie tradycyjnej dla wsi zieleni liściastej na iglastą.

Przeprowadzona ocena oraz analiza materiału zabranego w tym zakresie pozwala stwierdzić, że istnieje bardzo duże regionalne zróżnicowanie zasobów dziedzictwa kulturowego wsi, zarówno w zakresie typów architektoniczno-fizjonomicznych, jak i stanu ich zachowania. Pod tym względem do uczestnictwa w sieci predysponowane są przede wszystkim wsie obszarów, które zostały przyłączone do Polski w 1945 roku (regiony: warmińsko-mazurski, lubuski, dolnośląski, opolski, zachodniopomorski). Stopień zachowania wiejskiego dziedzictwa materialnego wynika w dużej mierze ze zróżnicowania materiału budowlanego oraz standardu obiektów. Najbardziej negatywnie odbiło się to na stanie zachowania dziedzictwa kulturowego w Polsce środkowej (łódzkie, mazowieckie, kujawsko-pomorskie, świętokrzyskie), gdzie model powojennych przekształceń doprowadził do całkowitej zagłady budownictwa drewnianego, które w chwili obecnej można oglądać prawie wyłącznie w skansenach. Kompleksy obiektów o bardziej trwałych podstawach budowlanych (kamień, cegła, szachulec) i o wyższym standardzie zamieszkiwania, przejęte po w większości przesiedlonych społecznościach niemieckich, są obecnie główną bazą dla wyszukiwania wsi do sieci, których potencjał w tym zakresie jest bardzo wysoki, choć oczywiście w wielu już przypadkach degradacja zasobów i tu jest bardzo duża.

\section{Dyskusja}

$\mathrm{Na}$ regionalne peryferia, w obrębie których leży większość wsi mających duży potencjał do wejścia do sieci, należy spojrzeć jako teren innowacyjnych działań, które mogą podnieść ich rangę społeczną i ekonomiczną. W wiejskich obszarach peryferyjnych znajduje się wiele zasobów, które przy zastosowaniu odpowiednich instrumentów mogą przerodzić się w atrakcyjne dla zewnętrznych odbiorców miejsca wypoczynku, zamieszkania, a także dzięki nowym technologiom, również $\mathrm{w}$ miejsca pracy. Wsie o odpowiednio wysokim potencjale uczestnictwa w sieci mogą w przyszłości stać się lokalnymi ogniskami rozwoju społeczno-ekonomicznego. 
Najbardziej palącym problemem rozwoju wsi poddanych ocenie jest utrzymanie zasobów, zwłaszcza cennych historycznych układów ruralistycznych (rozplanowanie i obiekty), w stanie umożliwiającym ich właściwą ekspozycję oraz odbiór estetyczny. Degradacja cennej zabudowy, zwłaszcza tej znajdującej w rękach prywatnych (np. zagrody), jest bardzo duża i tylko nieliczne wsie mogą pochwalić się kompleksowym charakterem utrzymania obiektów na wysokim poziomie. Procesom odnowy, a często nawet podstawowego zabezpieczenia budynków przed niszczeniem, nie sprzyja niska społeczna świadomość wartości historycznej oraz brak odpowiedzialności za przekazanie tego dziedzictwa kolejnym pokoleniom. Dla wielu wsi o wysokich walorach architektonicznych i układów ruralistycznych kluczowe będzie najbliższe 15-20 lat, kiedy może dokonać się zagłada podstawowych zasobów, które w obecnej chwili decydują jeszcze o zainteresowaniu wsią przez instytucje rozwoju i odnowy wsi, jak i pasjonatów dziedzictwa historycznego.

Jedną z cech, która obniża potencjał prawie wszystkich ocenianych wsi jest niska estetyka ogrodzeń, zwłaszcza prywatnych posesji. Ogrodzenia posesji na obecnym etapie przemian krajobrazu osiedli wiejskich w najmniejszym stopniu stanowią oryginalny (zgodny) element wyposażenia wsi. Większość z nich to tani substytut tego, co powinno być dopełniającymi całość składnikami środowiska architektoniczno-fizjonomicznego.

Istotnym uwarunkowaniem współczesnych przemian wsi o dużych możliwościach wejścia do sieci jest aktywność społeczna mieszkańców, którą można interpretować jako oznaki „nowej” wiejskości związanej z wkraczaniem wielu obszarów wiejskich w post-produkcyjny etap rozwoju. Podstawową cechą „nowej” wiejskości jest traktowanie wsi jako alternatywnego wobec miejskiego (zurbanizowanego) środowiska zamieszkania i pracy, co jest wyrazem wzrostu świadomości walorów wsi. Dotyczy to zarówno nowych mieszkańców, zafascynowanych oryginalnym dziedzictwem wsi i możliwościami, które płyną z jego twórczego rozwoju oraz części autochtonów cechujących się wzrostem zainteresowania własną tożsamością połączonym z możliwościami uzyskania wymiernych zysków na skutek obsługi turystów oraz grup społecznych poszukujących nowych doznań kulturowych i wrażliwych na bodźce płynące z wiejskiego „milieu”.

Recepta na sukces obejmuje wiele elementów, które należy zauważyć i docenić. Wśród tych najważniejszych należy wskazać atrakcyjny układ przestrzenny, w którym nie brakuje miejsc centralnych ogniskujących funkcje poznawcze i wypoczynkowe, społeczną świadomość walorów własnego dziedzictwa i umiejętność opowiedzenia o nich (określenie powodu pobytu), istnienie instytucji długiego trwania odwołujących się do pamięci historycznej oraz wspólnotowych działań, umiejętność tworzenia nośników narracji umiejscowionych w środowisku wewnętrznym, ukształtowaną już w jakiejś formie ścieżkę własnego rozwoju 
opartą o własne zasoby (rozwinięte funkcje turystyczne), a także funkcjonowanie w lokalnej i regionalnej sieci miejscowości o różnych funkcjach i walorach środowiska naturalnego i antropogenicznego (regiony turystyczne).

Niezwykle ważnym czynnikiem rozwoju ciekawych wsi i ich uczestnictwa w sieci jest pomoc i wsparcie ze strony samorządów lokalnych, od których zależy uruchomienie różnych instrumentów promocji, instytucjonalnych i prawnych. Chwiejność polityczno-administracyjna i brak długofalowej wizji rozwoju miejscowości, w tym wysokie oczekiwania w krótkim czasie, mogą prowadzić do osłabienia członkostwa w sieci (np. utrata kluczowych zasobów, spadek aktywności społeczności lokalnej, wewnętrzna konkurencja). Każda wieś, u której stwierdzono duży potencjał uczestnictwa w sieci, oprócz cech wspólnych dla wszystkich członków (typowy zestaw cech, dzięki którym możliwy jest sukces) ma pewne własne oryginalne uwarunkowania rozwoju, w tym niepowtarzalne dla innych zasoby i tylko lokalne środowisko społeczne, tj. decydenci, liderzy, społeczności, jest w stanie je dostrzec, zrozumieć i odpowiednio wypromować na rzecz odbiorcy.

\section{LITERATURA}

Biczkowski M., 2013, Przestrzenna alokacja wsparcia finansowego z instrumentów wspólnej polityki rolnej $i$ ich wplyw na rozwój społeczno-gospodarczy obszarów wiejskich, „Acta Universitatis Lodziensis. Folia Geographica Socio-Oeconomica”, 13, s. 93-114.

Bukraba-Rylska I., 1992, Badanie kultury a odbudowa tożsamości wsi wspótczesnej, [w:] Wieruszewska M. (red.), Odnowa wsi. Między mitem a nadzieja, IRWiR PAN, Warszawa, s. 133-157.

Idziak W., Wilczyński R., 2013, Odnowa wsi. Przestrzeń, ludzie, działania, FAPA, Warszawa.

Kłodziński M., Błąd M., Wilczyński R. (red.), 2007, Odnowa wsi w integrującej się Europie, IRWiR, Warszawa.

Niedźwiedzka-Filipiak I., 2009, Wyróżniki krajobrazu i architektury wsi Polski poludniowo-zachodniej, Wydawnictwo Uniwersytetu Przyrodniczego, Wrocław.

Niedźwiedzka-Filipiak I., Wilczyński R., 2015, Walory miejscowości - tworzywem Sieci Najciekawszych Wsi, Urząd Marszałkowski Województwa Opolskiego, Opole.

Rudnicki R., 2010, Zróżnicowanie przestrzenne wykorzystania funduszy Unii Europejskiej przez gospodarstwa rolne w Polsce, Bogucki Wydawnictwo Naukowe, Poznań.

Wilczyński R., 2012a, Odnowa wsi z wykorzystaniem środków europejskich - niewykorzystana szansa na rewitalizacje, „Architektura Krajobrazu, Studia i Prezentacje”, 2(35), s. $4-22$.

Wilczyński R. (red.), 2012b, Sieć Najpiękniejszych Wsi. Opracowanie eksperckie projek$t u$, PROW, KSOW, Opole.

Wójcik M., 2010, Struktura i działanie - geograficzno-społeczna interpretacja oddziatywania funduszy Unii Europejskiej na przykladzie programu ,,Odnowa wsi”, [w:] Kacprzak E., Kołodziejczak A. (red.), Rola środków Unii Europejskiej w rozwoju obsza- 
rów wiejskich, „Studia Obszarów Wiejskich”, 24, Zespół Badań Obszarów Wiejskich Instytutu Geografii i Przestrzennego Zagospodarowania PAN, Komisja Obszarów Wiejskich PTG, Warszawa, s. 186-201.

Wójcik M., 2012, Geografia wsi w Polsce. Studium zmiany podstaw teoretyczno-metodologicznych, Wydawnictwo UŁ, Łódź.

\title{
CONDITIONS FOR THE CREATION OF"THE MOST INTERESTING VILLAGES’ NETWORK”. RESULTS OF THE EVALUATION OF THE FIFTY POLISH SETTLEMENTS
}

\begin{abstract}
Transformations that occur in Polish rural areas also impact tourism and recreation enterprises. Starting the rural development programs successfully activates processes of modernisation in many fields of social and economic life, including material base (infrastructure), which is an essential element in the functioning of settlement systems. The aim of this study is to present selected results of the expert analysis of 50 Polish villages, which are characterised by a high concentration of cultural values - material, institutional and spiritual. The assessment of a group of rural settlements was meant to determine the potential for creating the Network of the Most Interesting Villages (SNW). The article presents the factual basis for such evaluation, the differentiation in group of villages according to selected traits, especially those describing the infrastructural plane for developing the tourism and recreational functions.

The recipe for success includes many elements. The most important ones include attractive spatial configuration in which there is no shortage of central locations that are the focus of educational and recreational functions, the social awareness of the value of one's own heritage and the ability to describe it (the purpose of stay), the existence of long-lasting institutions referring to the historical memory and communal activities, the ability to create the media for narration placed in the internal environment, somewhat-formed path of its own development based on own resources (developed tourism functions), as well as participation in local and regional network of town with varying functions, and natural and anthropogenic environmental values (tourist regions).
\end{abstract}

Keywords Rural areas, cultural heritage, methods of settlements research.

Dr hab. Marcin Wójcik, prof. UŁ Katedra Geografii Regionalnej i Społecznej Wydział Nauk Geograficznych Uniwersytet Łódzki 